\title{
THE AUSTRALIAN ANT GENUS MAYRIELLA FOREL
}

\section{BY WILliaM MORTON WHEELER}

\section{Biological Laboratories, Harvard University}

The primitive Meranopline genus Mayriella was established by Forel more than thirty years ago for a minute worker ant, $M$. abstinens, taken by Gilbert Turner in Queensland. ${ }^{1}$ Since that time, except for brief consideration in Emery's volume on the Myrmicinæ in Wytsman's "Genera Insectorum" and citation in a few faunal lists, the insect has remained unnoticed. ${ }^{2}$ This neglect is due no doubt to its rare or very local occurrence and diminutive size. I find in my collection only a small number of specimens which are clearly referable to Mayriella, but they belong to two species. One of them is a worker of an undescribed species, another a cotype of abstinens received from Prof. Forel. There are also specimens of two subspecies of this form and the series of one of them comprises several females. The male Mayriella, unfortunately, is still unknown. In the following pages I include descriptions and figures of these forms, which are of interest in connection with two other primitive genera of Meranoplini, namely Willowsiella and Romblonella, which I have recently described. $^{3} \quad$ It seems advisable also to amplify Forel's generic diagnosis and to redescribe abstinens from the cotype.

\section{Mayriella Forel}

Worker. Monomorphic, minute, thickset, with hard, sculptured integument. Head rather large, shaped much

${ }^{1}$ Forel, A. Rev. Suisse Zool. 10, 1902, pp. 452-454.

${ }^{2}$ Viehmeyer (Ent. Mitteil. 13, 1924, p. 26) has, indeed, described a Mayriella overbecki from Trial Bay, New South Wales, but I fail to detect anything in his account that does not apply to the typical $M$. abstinens.

${ }^{3}$ Formicidæ of the Templeton Crocker Expedition, 1933. Proc. Cala. Acad. Sci. 21, 1934, p. 174-176, Fig. 1 and "Two New Genera of Myrmicine Ants from Papua and the Philippines," Proc. New England Zool. Soc., 1935, pp. 1-9, Fig. 2. 
as in Meranoplus. Eyes set obliquely, slightly in front of the middle of the head, moderately large and convex, but consisting of comparatively few hemispherical facets (only 4 or 5 in the greatest transverse diameter), elongateelliptical, produced inferoanteriorly as a distinct point. Ocelli absent. Mandibles rather small, with short, oblique, 4 -toothed apical borders. Clypeus short, its posterior portion forming an elevated, laterally marginate plate, terminating on each side anteriorly in a small, sharp tooth and extending back between the frontal carinæ. In profile the outline between the anterior edge of the median plate and the anterior border of the clypeus is strongly concave. Frontal carinæ widely separated, subangulate, laterally expanded and lamellate anteriorly but not reaching the sides of the head and hence more as in Triglyphothrix than in Meranoplus, continued backward as two sharply, only moderately divergent ridges which form the mesial borders of broad, deep, supraocular scrobes that are rounded posteriorly and each large enough to contain the whole folded antenna. Frontal area distinct, frontal groove obsolete. Antennæ 10-jointed; scape short, first funicular joint conspicuously enlarged, joints 2-7 short and transverse, the seventh longer than the others which are small and narrow, the two terminal joints forming a large club, the last joint of which is much larger than the penultimate, as long as the remainder of the funiculus without the first joint. When the antenna is folded into the scrobe, the club is turned mesially so that it overlies and conceals nearly the whole scape and fits into the space between the plate and depressed lateral portion of the clypeus. Thorax short and stout, the pronotum large, moderately convex, with sharply rectangular humeri and submarginate sides ; promesonotal and mesoëpinotal sutures obsolete, the latter replaced by a dorsally transverse, longitudinally costate groove; epinotum short and narrow, sloping, armed with a pair of teeth or spines which are placed low down; metasternal angles distinct but rounded. Petiole and postpetiole with well-developed but not enlarged nodes, the petiole subpedunculate anteriorly, with an anteroventral tooth. Gaster much as in Meranoplus, oval, with about 
three fourths of its dorsal surface consisting of the first segment. Sting apparently vestigial. Legs short; middle and hind tibiæ spurless; tarsal claws slender and simple.

Female. Very similar to the worker but decidedly larger and differing in the usual sexual characters. Eyes larger, with their pointed anterior ends terminating near the corners of the clypeus. Ocelli small, not closely approximated. Thorax narrower than the head; pronotum short, truncated anteriorly, with sharply rectangular humeri; mesonotum large, flattened above. Pedicel and gaster proportionally stouter than in the worker, the latter more elongate-elliptical. Wings long, narrow, pubescent, the anterior pair with well-developed, elongate pterostigma, open submarginal cell, a single long cubital cell and a small, discoidal cell; hind wings nearly veinless.

Genotype: Mayriella abstinens Forel

Mayriella resembles both Willowsiella and Romblonella in the shape of the head and thorax, the position of the eyes and the absence of promesonotal and mesoëpinotal sutures but differs from both in its much smaller size and in the number of antennal joints, which is 11 in Willowsiella and 12 in Romblonella, with 3-jointed clubs. Moreover, the former of these genera lacks antennal scrobes and both have the petiole greatly enlarged. This is true also of the postpetiole in Romblonella.

No observations have been published on the habits of Mayriella. My note-book shows that on Nov. 2, 1914, I found at Cairns, Queensland, three small colonies of $M$. abstinens nesting in sand. Each nest was a small regular crater slightly more than an inch in diameter, with a minute central entrance. Each colony comprised between 50 to 100 workers, which were huddled together with their scanty brood in small chambers only about an inch beneath the surface of the sand. The nests, except in their diminutive size, were exactly like those of several of the smaller species of Meranoplus (oceanus, nanus, etc.) which are common in sandy spots in the open Australian bush. Although I collected several of the abstinens workers I have since been unable to find them among my mounted material and suspect that they must have been lost among 
much larger ants collected on the same day and placed in the same vial. The type of the subsp. venustula, described below was taken by the late Mr. A. M. Lea "in rotting leaves," that of spinosior sp. nov. by the same collector "among fallen leaves."

The workers of the four known forms of Mayriella may be separated by means of the following table.

1. Epinotum armed with spines which are at least twice as long as the diameter of their bases; petiolar node truncate above in profile; anterior corners of postpetiole distinctly produced and subdentate.........

spinosior sp. nov.

Epinotum armed with teeth, which are not longer than the width of their bases; petiolar node with rounded summit; anterior corners of postpetiole not pro-

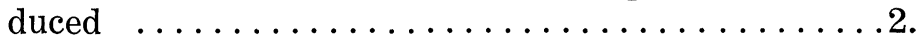

2. Head, thorax and pedicel dark brown; sculpture coarse. abstinens venustula subsp. nov.

Head, thorax and pedicel paler, yellow-brown; sculpture

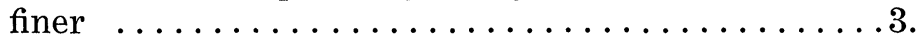

3. Epinotal teeth blunt, shorter than the width of their bases; postpetiole above smooth and shining....... abstinens Forel (typical)

Epinotal teeth acute, as long as the width of their bases; sculpture coarser; postpetiole above finely punctate, subopaque .........abstinens hackeri subsp. nov.

\section{Mayriella abstinens Forel}

$$
\text { (Fig. } 1 \mathrm{a}-\mathrm{c} \text { ) }
$$

Worker. Length 1.4-1.5 $\mathrm{mm}$.

Head subtrapezoidal, slightly longer than broad, narrower in front than behind, with rounded sides and posterior corners and broadly sinuate posterior border. Mandibles rather flat, with straight external borders. Elevated median plate of clypeus subtrapezoidal, slightly longer than broad, broader in front than behind, its surface distinctly concave, its anterior border broadly emarginate between the teeth. Antennal scapes short, scarcely reaching to the posterior fourth of the head, thin at the base, swollen in the middle; first funicular joint keg-shaped, one and one- 
half times as long as broad, joints 2-6 twice as broad as long, the seventh distinctly longer, the eighth slightly broader than long, one-third as long as the more swollen terminal joint. Thorax less than twice as long as broad; promesonotum excluding the neck narrower than the head, subtrapezoidal, anteriorly twice as broad as posteriorly, with feebly rounded anterior and nearly straight, marginate anterior and lateral borders; in profile rising rather abruptly from the neck, moderately and evenly rounded above, slightly sloping behind to the short, feebly costate, transverse mesoëpinotal groove or impression; base of epinotum quadrate, sloping with slightly raised anterior border and marginate sides, the marginations enlarging below to form a pair of small, blunt, flattened teeth, which are shorter than their basal diameter; epinotal declivity much shorter than the base, continuing down in the same sloping plane between the metasternal lobes. Petiole but little longer than broad, narrowed anteriorly, its node broader than long, subrectangular, with straight, transverse anterior border and straight, parallel sides; in profile subcuneate, higher than long, with straight ascending anterior slope, meeting the shorter, evenly convex posterior slope at a distinct angle; ventral surface of petiole straight and horizontal, the tooth at its anterior end blunt and translucent. Postpetiole from above nearly one-third broader than the petiole, one and one-half times as broad as long, rounded-oblong; in profile broadly rounded above, ventrally slightly convex in the middle. Gaster about as large as the head, convex above and below, its anterior border concave in the middle, its anterior corners marginate on the sides.

Shining; head, thorax and petiole more subopaque; mandibles smooth, sparsely and very finely punctate; sides of clypeus transversely rugulose, its elevated median plate smooth and shining. Head, thorax, petiole and ventral portion of postpetiole very finely and microscopically, the scrobes, neck, pleuræ, posterior surface of epinotum, the petiole and ventral portion of the postpetiole more coarsely and evenly reticulate; front of head also feebly, longitudinally rugulose, its posterior corners and the promesono- 
tum with a coarser, superimposed reticulate rugulosity and with the spaces between the rugules occupied by shallow, circular foveolæ, the cavities of which, however, exhibit the fundamental microscopic reticulation. Node of post-
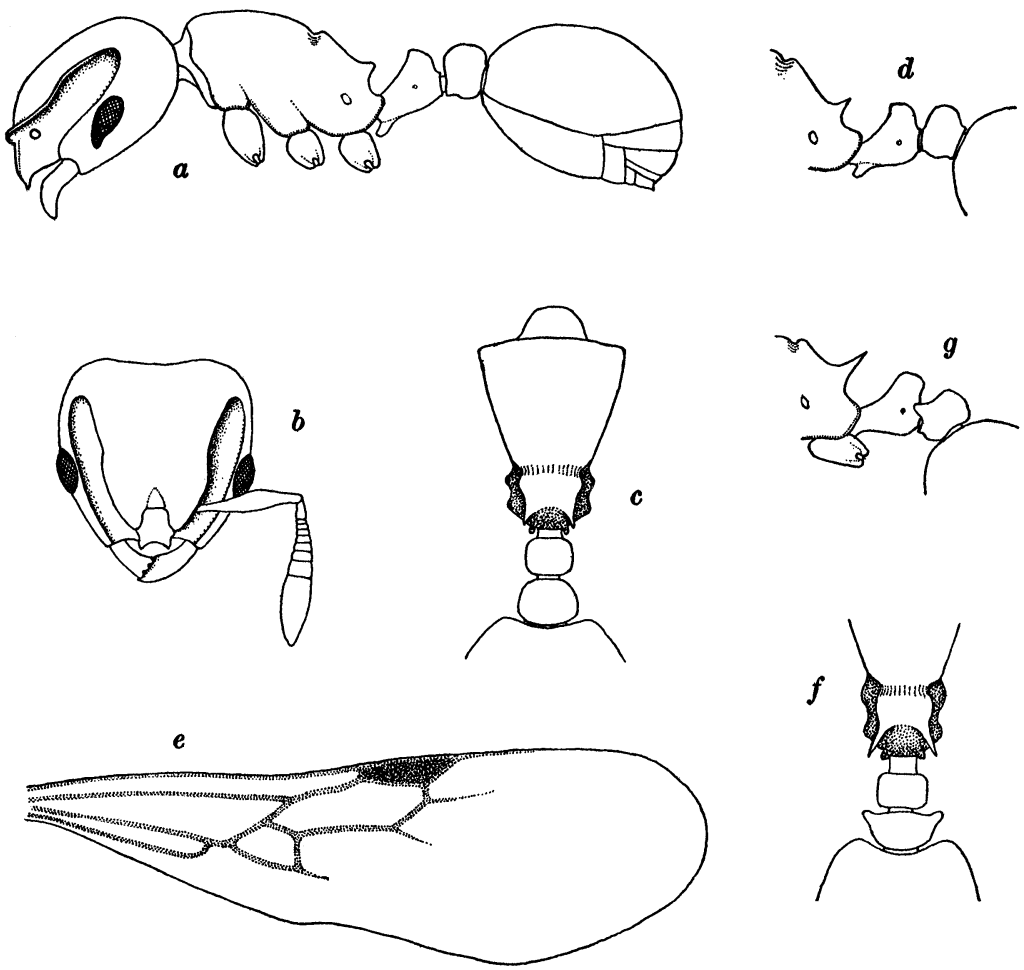

Fig. 1. a, Mayriella abstinens Forel, worker in profile; $b$, head of same dorsal view; $c$, thorax and pedicel, dorsal view; $d, M$. abstinens hackeri subsp. nov., epinotum and pedicel of worker in profile; $e$, wing of female; $f, M$. spinosior sp. nov., epinotum and pedicel of worker, dorsal view; $g$, same in profile.

petiole smooth and more shining than the petiolar node; gaster, legs and antennæ very smooth and shining.

Pilosity white, erect, long, and very sparse on the body, more abundant, much shorter and finer on the appendages oblique on the antennal scapes and funiculi, subappressed on the femora and tibiæ. 
Head, thorax and pedicel yellowish-brown or testaceous; mandibles, antennæ, gaster and legs, including the coxæ, paler, clearer yellow; mandibular teeth brown.

Redescribed from a single cotype specimen from Mackay, Queensland (Gilbert Turner). As previously suggested, Viehmeyer's $M$. overbecki from Trial Bay, New South Wales, seems to me to be synonymous with the typical form of abstinens. The female, which he described very briefly, appears to be very similar to the corresponding caste of the following subspecies.

Mayriella abstinens hackeri subsp. nov.

(Fig. 1, d-e)

Worker. Of the same size and otherwise very similar to the typical abstinens, but the promesonotum is slightly narrower and the teeth on the epinotum are distinctly larger, as long as broad and acute, the petiole somewhat shorter, with the anterior slope of the node concave instead of straight in profile, so that it forms a sharper angle with the convex posterior slope.

Head, thorax and petiole more shining and the sculpture of the head and promesonotum distinctly finer, the superimposed rugulosity more delicate, less distinctly longitudinal on the front, with the round foveolæ shallower though more numerous on the head. Postpetiolar node not smooth as in the typical abstinens but like the node of the petiole very finely and densely punctulate.

Long, sparse pilosity on the body as in the type, but the hairs on the antennæ and legs distinctly shorter, sparser and appressed.

Color as in the type but the most mature specimens have the gaster concolorous with the head, thorax and pedicel.

Female. Length about $2.7 \mathrm{~mm}$.

Differing from the worker in the following characters: Head fully as broad as long or slightly broader; eyes larger, more than twice as long as broad, with about eight facets in their greatest transverse diameter. Mesonotum as broad as long, narrowed and bluntly pointed anteriorly; scutellum semicircular, flattened; base of epinotum scarcely longer than the declivity, the teeth stouter. Posterior slope of 
petiolar node flat, meeting the slightly concave anterior slope at somewhat less than a right angle, the transverse summit formed by their juncture distinctly sinuate in the middle. Postpetiolar node oblong, nearly twice as broad as long.

Reticulate rugosity of head and pronotum much coarser than in the worker, with abundant, deeper, circular foveolæ; mesonotum and scutellum smoother, without reticulate rugules and with smaller and more scattered foveolæ, especially on the anterior and median portion of the mesonotum. Scrobes, pleuræ and epinotum regularly and sharply reticulate-rugulose, or rather coarsely, densely and evenly punctate ("thimble-punctured," to use the French expression) ; petiole and postpetiole less shining and more coarsely punctulate than in the worker. Gaster and legs under a high magnification very finely and superficially shagreened.

Pilosity as in the worker but the long sparse hairs on the body are proportionally shorter and more flexuous and on the gaster more numerous.

Head, thorax and pedicel darker and more ferruginous than in the worker; each ocellus with a round black spot at its inner orbit; posterior border of scutellum and a pair of large elongate parapsidal spots dark brown. Membranes and veins of wings clear and colorless, pterostigma brown.

Described from four workers and six females taken July 20, 1915, by Mr. Henry Hacker near Brisbane, Queensland.

Mayriella abstinens venustula subsp. nov.

Worker. Length $1.3 \mathrm{~mm}$.

Very similar structurally to the typical abstinens even in the shape of the epinotal teeth, which though distinctly larger are nevertheless blunt and shorter than their basal diameter. Longitudinal costæ in the mesoëpinotal groove more distinct. Anterior slope of petiolar node slightly concave in profile and therefore more as in the subsp. hackeri.

Head, thorax and pedicel less shining owing to the greater sharpness of all four components of the sculpture namely the basal microscopic reticulation or punctulation, the coarser, even thimble-puncturing of the scrobes, neck, pleuræ, epinotum and ventral and lateral surfaces of the 
petiole and postpetiole, the superimposed reticulate rugulosity and the foveolation of the head and promesonotum. The rugules are longitudinal only on the anterior expanded portions of the frontal carinæ; the foveolæ are abundant and regularly distributed on the head and anterior half of the promesonotum, its posterior half being thimble-punctured like the epinotum; the nodes of the petiole and postpetiole are more strongly punctulate than in the typical abstinens and its subsp. hackeri, though more shining than the basal portions of their respective segments.

Pilosity as in the typical abstinens.

Head, thorax and pedicel much darker, being dark brown and contrasting sharply with the clear yellow coloration of the mandibles, antennæ, legs and gaster.

Described from a single specimen taken by Mr. A. M. Lea "in rotting leaves" on Mt. Tambourine, Queensland.

Mayriella spinosior sp. nov.

(Fig. 1, $\mathrm{f}-\mathrm{g}$ )

Worker. Length $1.3 \mathrm{~mm}$.

Of the same size as abstinens but differing in the following structural characters: Head broader, fully as broad as long, more rectangular, with somewhat more angular posterior corners, less sinuate posterior border and more widely separated frontal carinæ. Median elevated plate of clypeus shorter, with less developed teeth and more semicircularly excised anterior border. Sides of promesonotum less distinctly submarginate, humoral angles less acute, mesoëpinotal groove shallower and the epinotal teeth replaced by spines which are fully twice as long as their basal diameter, nearly as long as the base of the epinotum and directed upward and outward and somewhat backward. Petiole as long as high, its node in profile truncated above owing to what corresponds to the posterior slope in abstinens being angulate in the middle. The anterior border of this truncated area, which is subtrapezoidal and slightly broader behind than in front, is sharply marginate. Postpetiole from above of similar shape but reversed, that is, broader in front than behind, with the anterior corners distinctly produced and bluntly subdentiform. Anterior corners of gaster not marginate. 
Mandibles finely longitudinally striate at their external borders. Sculpture of head and promesonotum decidedly coarser than in any of the forms of abstinens, consisting of the basal microscopic reticulation overlaid by a regular polygonally reticulate rugosity, without rounded foveolæ in the meshes. The rugæ are distinctly longitudinal on the front of the head. Thimble-punctuation of the scrobes, neck, pleuræ, epinotum and ventral portions of the petiole and postpetiole finer than in abstinens venustula; the nodes subopaque, finely and densely punctate.

Pilosity pale yellowish, in length and distribution like that of the subsp. hackeri.

Thorax, pedicel and gaster yellowish ferruginous, the head somewhat darker and more brownish; mandibles, antennæ and legs, including the coxæ, brownish yellow ; mandibular teeth brown.

Described from a single specimen taken by Mr. A. M. Lea "among fallen leaves" in the Cairns District, Queensland. 

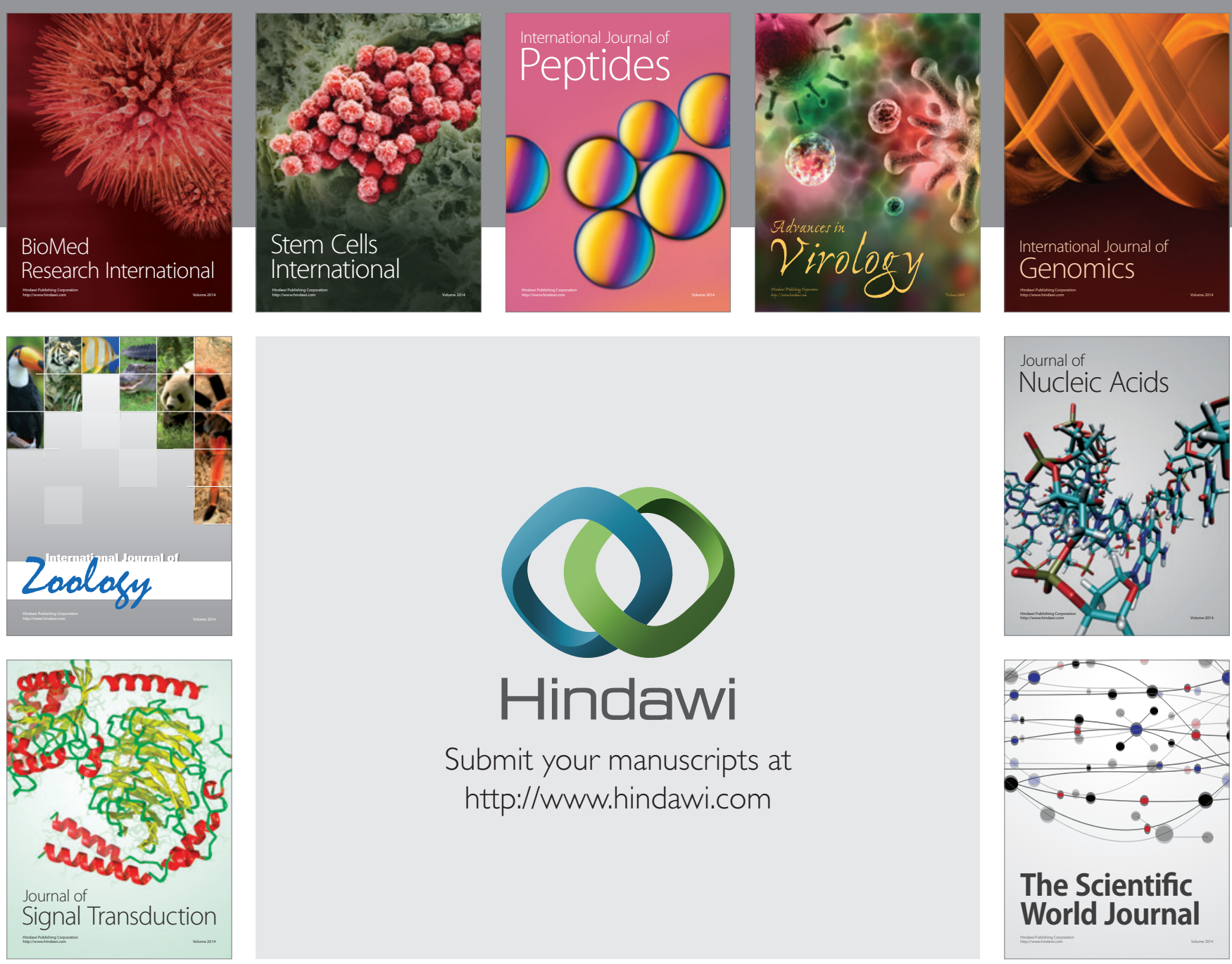

Submit your manuscripts at

http://www.hindawi.com
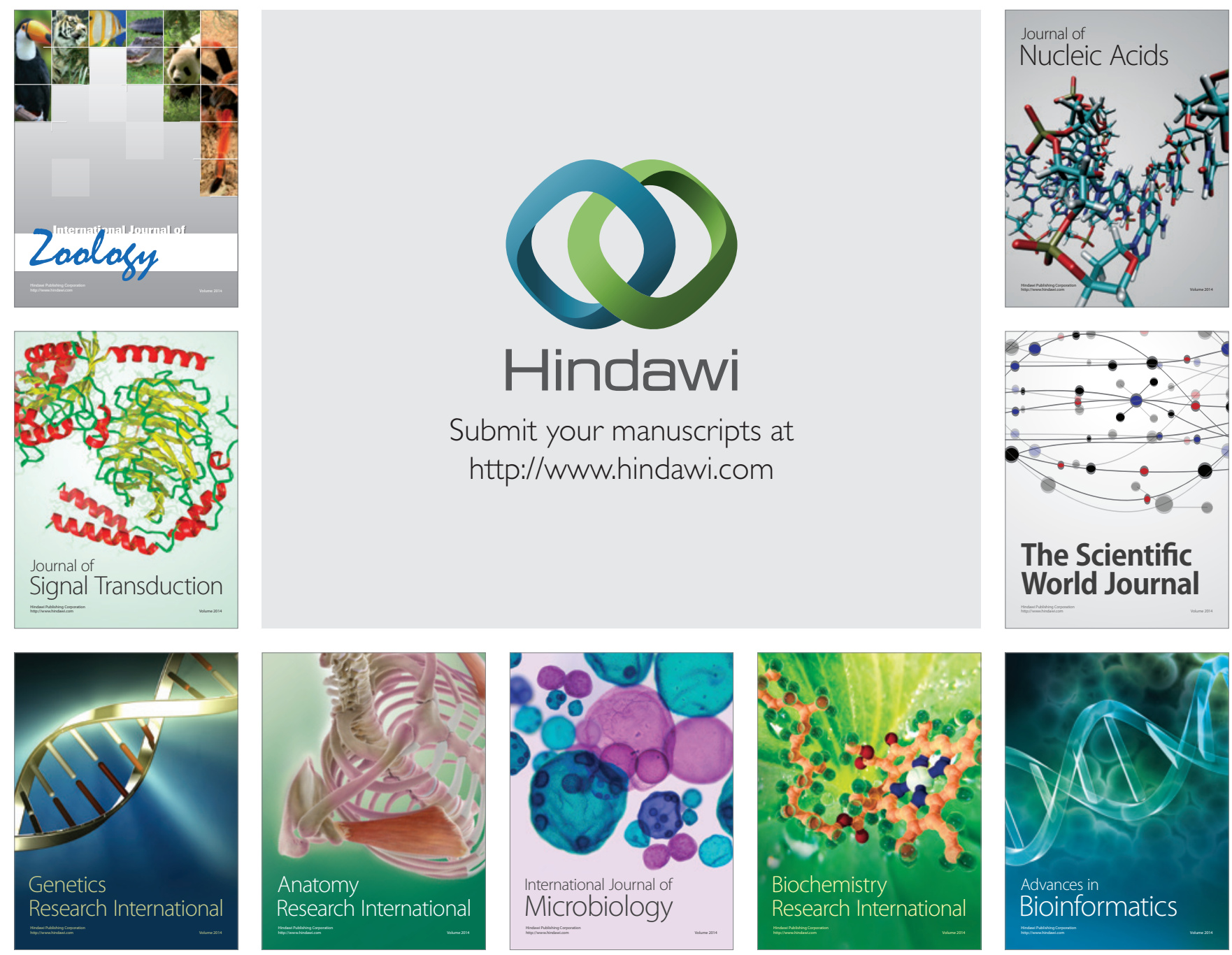

The Scientific World Journal
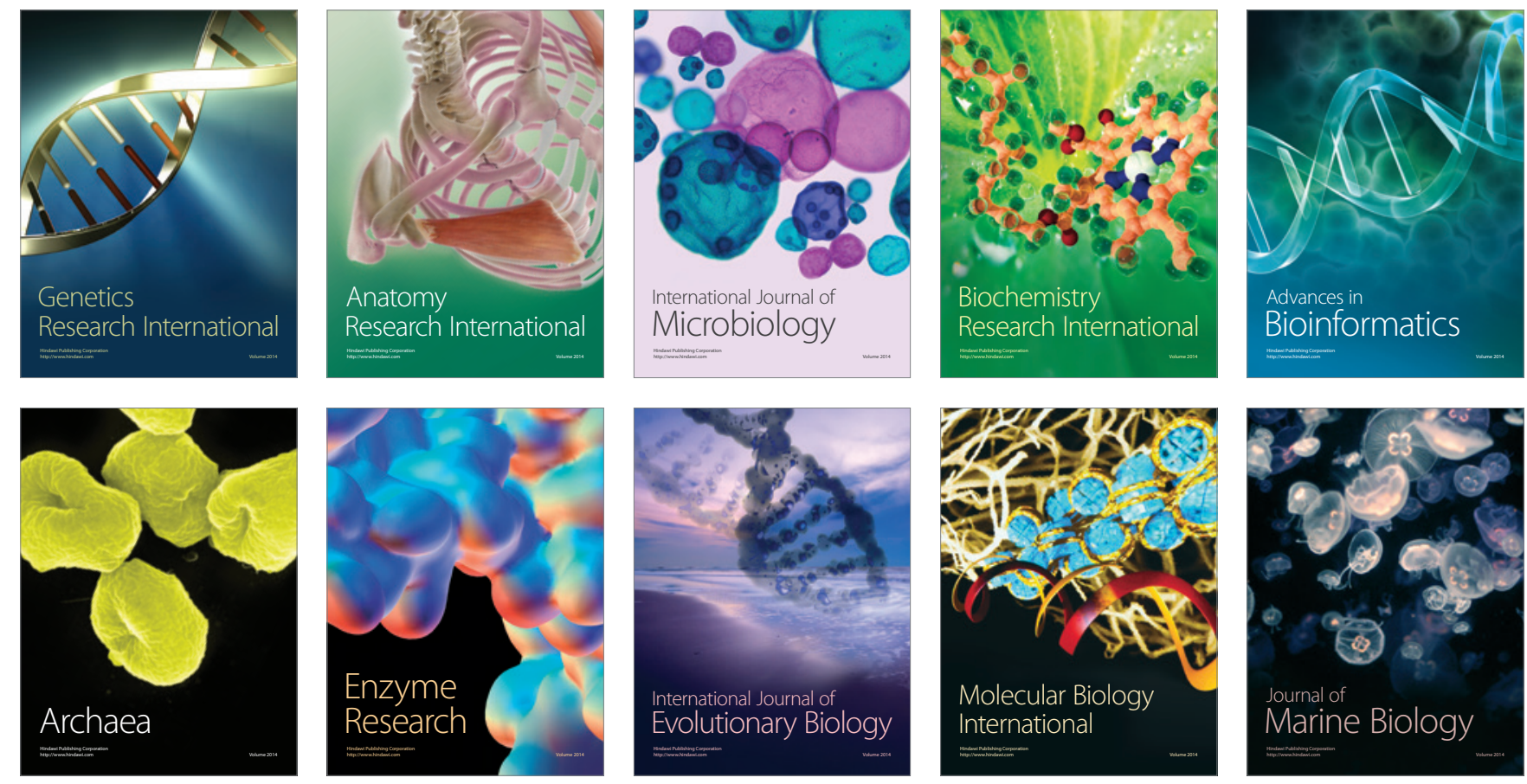